\title{
Financial Development and Consumption
}

\author{
An econometric analysis of the correlation between the selected indicators of financial \\ development and final consumption as a percentage of Gross Domestic Product
}

\author{
Maryam Almasifard \\ Department of Agricultural and Applied Economics \\ Texas Tech University \\ Lubbock, TX, USA \\ m.almasifard@ttu.edu
}

\author{
Mohammadhossein Saeedi \\ Department of Industrial, Manufacturing and Systems Engineering \\ Texas Tech University \\ Lubbock, TX, USA \\ mohammad.saeedi@ttu.edu
}

\begin{abstract}
The paper use panel regression method to assess the relationship between a certain indicator of financial development and consumption as a share of Gross Domestic Product (GDP). By analyzing a sample of eight central and eastern European countries (Hungary, Bulgaria, Poland, Czech Republic, Slovenia, Romania, Ukraine and Belarus), between 1993 and 2010, we realized that the lagged value of final consumption expenditure (as a percentage of GDP) has a positive and statistically significant effect on the share of final consumption expenditure in Gross Domestic Product. It should be mentioned that real interest rate also shows a positive and statistically significant effect.
\end{abstract}

Keywords-financial development; gross domestic product; final consumption; panel data regression

\section{INTRODUCTION}

In the last decades, some economists have argued that the factor of financial development can affect households' decision regarding the allocation of their disposable income between saving and consumption. Although there is not a general agreement among economists for a single and unique definition of financial development, there appears to be an agreement on its main factors. In the definition of financial development, it can be stated that financial development is rules and policies which are helpful for producing more effective and efficient market. Improvement in policy and strategy also enhances the quality of competition in the market environment [1]. Moreover, continuous improvement is remarkably essential [2]. In fact, financial development creates a situation where access to credit will be easier for the different agents even minorities group in an economy.

Financial development can be explained in the same way as growing in the quantity and quality of private banks and financial institutions or growing the share of participation of private banks in different sectors of financial markets. Some economists go through financial stability for presenting a proper definition of financial development. The effect of financial development on the economic growth rate of a country depends on the level of political and economic freedom, the level of financial development of the country and even the time which these developments are introduced in countries. Rioja and Valev (2004) argue that financial development does not show positive effect all the time, or if does the size of these effects differ by the level of the development [3]. On the other hand, Lartey (2010) argues that these effects are constant and are independent of the level of development and all the times are positive and meaningful [4].

In general financial development refers to the situation when private sections of economy participate more actively in financial activities of a certain economy. Financial development can be assessed by alternative ways such as size, accessibility of capital, depth, efficiency and stability of the whole financial sectors, it can be evaluated by inspecting the operation of different sectors of the economy such as banks, financial markets, bond markets or in general different financial institutions.

Economists used different approaches to defining financial development. Based on the report published by World Bank (2005), financial development is the factors, rules, and policies which are helpful for producing more effective and efficient economy [5]. On the other hand, some economists presented a more precise definition for financial development by concentrating on its major roles in an economy. He argued that financial development can be defined by its' role and its' contribution to economy such as collecting additional information about new possible investment, monitoring the performance of agents after distribution of capitals, accelerating the transaction process and handling risks, introducing new ways for pooling resources and finally introducing more efficient ways to trade goods and services. Aghion et al. (2005) argue that countries with either high level of financial development or sufficient level of technology converge to the borderline growth rate and per-capita GDP [6]. However, countries who are far from these two factors will diverge. Based on Kelly and Mavrotas (2008), financial development work as an accelerator for economic growth [7].

\section{DATA AND METHODOLOGY}

\section{A. Panel Data Regression}

The term panel data refers to the pooling of observation on a cross-section of household, countries, firms over several time periods. The data are usually collected over time and over the same individuals and then a regression is run over these two dimensions. 
There are several advantages for using panel data regression like:

- Controlling for individual heterogeneity: while panel data suggest that individuals are heterogeneous, timeseries and cross-section do not control for this heterogeneity,

- Panel data provide more informative data, more variability, less collinearity and also more degree of freedom and efficiency,

- Panel data are better able to study the dynamics of adjustment,

- Panel data are better to classify and measure effects that are simply not measurable in pure cross-section or pure time series analysis,

- Panel data give us the chance to collect more data at the micro level and be more precise in the micro level analysis.

By using panel data for the sample period of 1993-2010 for eight central and east European Countries (Hungary, Bulgaria, Poland, Czech Republic, Slovenia, Romania, Ukraine and Belarus), we estimate four alternative specifications of the general model of the final consumption expenditures as a share of GDP. In fact, by running these regression models we try to determine the effect of one-year lagged value of final consumption expenditure as a percentage of GDP, Real interest rate, Growth rate of GDP, Total credit provided by banking sector (as a share of GDP), Money and quasi money as a percentage of GDP, and GDP per capita on the final consumption expenditure (as a percentage of GDP).

\section{B. Regression Model}

A general form of final consumption expenditure as a percentage of GDP is

$$
\mathrm{y}_{\mathrm{it}}=\alpha+\beta \mathrm{X}_{\mathrm{it}}+\varepsilon_{\mathrm{it}} \quad \mathrm{i}=1, \ldots, \mathrm{N} ; \quad \mathrm{t}=1, \ldots, \mathrm{T}
$$

Where

- $y_{i t}$ is the final consumption as a percentage of GDP in country $\mathrm{i}$ at time $\mathrm{t}$

- $\mathrm{X}_{\mathrm{it}}$ is the vector of independent variables such as

- $\mathrm{C}_{-1}$ (one-period lagged value of final consumption as a percentage of GDP)

- I (Real interest rate)

- $\quad \mathrm{M}$ (sum of money and quasi-money as a percentage of GDP (M2/GDP)

- DC (domestic credit provided by the banking sector as a percentage of GDP)

- LP (logarithm of per capita real GDP)

- GGDP (growth rate of real GDP)

\section{EMPIRICAL RESULTS}

In this section, 2 different tables will be provided; the first table is the correlation matrix which presents the correlation between the dependent variable and all the independent variables. In the second table, the results of panel estimation of the four different regressions for final consumption expenditures as a percentage of GDP have been summarized.

Each column in Table 2 reports a different regression and each row reports a coefficient estimate and t-statistic. And the adjusted R-squared value of each regression is given at the bottom of the corresponding column.

TABLE I. CORRELATION MATRIX

\begin{tabular}{|c|l|l|l|l|l|l|l|}
\hline & \multicolumn{1}{|c|}{$\mathbf{C}$} & \multicolumn{1}{|c|}{$\mathbf{C}_{\mathbf{-}}$} & \multicolumn{1}{|c|}{ M } & \multicolumn{1}{|c|}{ DC } & GGDP & \multicolumn{1}{|c|}{ LP } & I \\
\hline $\mathbf{C}$ & 1.000 & 0.902 & -0.115 & -0.100 & -0.004 & -0.421 & 0.203 \\
\hline $\mathbf{C}_{\mathbf{- 1}}$ & 0.902 & 1.000 & -0.166 & -0.194 & -0.071 & -0.486 & 0.067 \\
\hline $\mathbf{M}$ & -0.115 & -0.166 & 1.000 & 0.817 & -0.083 & 0.038 & 0.304 \\
\hline DC & -0.100 & -0.194 & 0.817 & 1.000 & -0.188 & 0.182 & 0.306 \\
\hline GGDP & -0.004 & -0.071 & -0.083 & -0.188 & 1.000 & 0.124 & 0.294 \\
\hline LP & -0.421 & -0.486 & 0.038 & 0.182 & 0.124 & 1.000 & -0.163 \\
\hline I & 0.203 & 0.067 & 0.304 & 0.306 & 0.294 & -0.163 & 1.000 \\
\hline
\end{tabular}

TABLE II. THE IMPACT OF FINANCIAL DEVELOPMENT ON THE CONSUMPTION (As PERCENTAGE OF GDP)

\begin{tabular}{|l|l|l|l|l|}
\hline \multicolumn{5}{|c|}{ Dependent Variable: C } \\
\hline Regressor & Equation (1) & Equation (2) & Equation (3) & Equation (4) \\
\hline & 2.67 & 1.89 & 5.62 & 3.96 \\
Constant & $(0.58)$ & $(0.45)$ & $(1.59)$ & $(1.03)$ \\
\hline & 0.95 & 0.96 & 0.93 & 0.94 \\
C-1 $_{-1}$ & $(22.22)^{*}$ & $(23.62)^{*}$ & $(24.12)^{*}$ & $(23.01)^{*}$ \\
\hline & 0.04 & 0.04 & 0.04 & 0.03 \\
I & $(4.54)^{*}$ & $(4.44)^{*}$ & $(3.81)^{*}$ & $(2.92)^{*}$ \\
\hline & 0.004 & & 0.003 & \\
M & $(-0.23)$ & & $(-0.14)$ & \\
\hline & & 0.01 & & 0.01 \\
DC & & $(0.43)$ & & $(0.56)$ \\
\hline & & & 0.02 & 0.03 \\
GGDP & & & $(0.45)$ & $(0.68)$ \\
\hline & & 0.11 & & \\
LP & 0.12 & $(1.13)$ & & \\
\hline$R^{2}$ & $(1.07)$ & 0.84 & 0.84 & 0.84 \\
\hline
\end{tabular}

a. These regressions are estimated using unbalanced panel data for the eight countries in our sample from 1993-2010 (137 observations total) b. -Heteroskedasticity - robust standard errors are given in parentheses under the coefficients c. *.The individual coefficient is the statistically significant at $1 \%$ level.

In what follows we first summarize the basic findings reported in Table 2 and then discuss their implications particularly for policy making:

1) Real interest rate has been found to have a positive and statistically significant effect on the dependent variable in all the four equations.

2) One-period lagged value of the dependent variable has a positive and highly significant effect on the dependent variable in all the four equations.

3) $\quad \mathrm{M}(\mathrm{M} 2 / \mathrm{GDP})$ has been found to have a statistically insignificant negative effect on the dependent variable (C) in all the regression equations.

4) DC (domestic credit provided by the banking sector as a percentage of GDP) has a positive effect on the dependent 
variable (C) in all the specifications of the estimated model. But this effect is not statistically significant.

5) The coefficient of GGDP (growth rate of real GDP) is also positive but statistically insignificant as can be observed in regression models 3 and 4.

6) The coefficient of LP (per capita real GDP) is positive but statistically insignificant as can be observed in regression models 1 and 2 .

The most critical insights that one can derive from the estimation results summarized above are related to the positive effect and highly significant of real interest rate on consumption; higher real interest rates have been found to be associated with higher GDP share of consumption expenditures. We can argue that for the average country in our sample, the(positive) income effect of an increase in real interest rate seems to have dominated its (negative) substitution effects on consumption. This finding might yield critical insights for policy makers of the average country in our sample. One of these policy insights is the possibility of expansionary monetary policy targeting at inspiring the domestic economy (through a reduction in real interest rates) leading to a contraction in output (and therefore employment) through its adverse effects on consumption. This possibility in particularly relevant for the countries where the responsiveness of investment to real interest rate is small making the net effect of sufficiently large reduction in real interest rate (on aggregate demand) negative due to the contraction in household demand for final consumer goods and services.

\section{CONCLUSION}

In this paper, we used different proxies for financial development to investigate the relationship between each one of them and consumption (as a share of GDP) in a sample of eight Central and East European countries. Based on panel regression analysis and general trends in the macro-economy of selected countries, regression results show that lagged value of final consumption expenditure as a percentage of GDP has a positive effect on final consumption expenditure (as a percentage of GDP) in selected central and east European countries. In addition, it should be mentioned that this specific variable has a significant effect on the share of final consumption expenditure in GDP in this selected group of countries (significant level is $1 \%$ ).

Next variable is real interest rate. Generally, real interest rate has a negative effect on the final consumption expenditure (as a share of GDP) which means people prefer to save more and consume less when real interest rate increases; so by increasing real interest rate, saving rate will increase and consumption rate will decrease. As a result of increasing real interest rate people prefer to allocate more portion of their disposable income for saving, put this money in the saving account and earn more money as a higher interest rate and become wealthier in future, they choose to save more now and consume more in the future. The interesting point in these countries is that by increasing real interest rate share of final consumption expenditure in GDP increase significantly and consequently saving rate decrease, this means that households in these certain countries as a group perfect to consume more and save less by increasing real interest rate. The significant level of real interest rate in these cases is $1 \%$.

In all these four models, credit provided by banking sector shows a positive but insignificant effect on the share of final consumption expenditure as a percentage of GDP which means variation of this certain variable doesn't have significant effect on the variation of the share of final consumption expenditure as a percentage of GDP in this group of countries. Based on Çiftçioğlu and Almasifard (2015), financial development has a statistically significant negative effect on consumption when it is proxied by the ratio of money and quasi-money to GDP [8]. However, Almasifard (2013) has not been able to detect a similar effect on consumption in case of the ratio of domestic credit to GDP. She argued that the effect is opposite in nature (positive) but statistically insignificant [9].

Next variable is GDP per capita which act exactly like the credit provided by the banking sector. This variable has a positive but again insignificant effect on the share of final consumption expenditure as a percentage of GDP. The last variable is growth rate of GDP (annual percentage) which shows a positive and insignificant effect on the share of final consumption expenditure.

\section{REFERENCES}

[1] S. T. Khorasani, "Design-Driven Integrated-Comprehensive Model CDFS Strategic Relationships. In ASME 2014 International Design Engineering Technical Conferences and Computers and Information in Engineering Conference", American Society of Mechanical Engineers. , August 2014 , pp. V004T06A020-V004T06A020.

[2] S. M. Asio and S. T. Khorasani, "Social Media: A Platform for Innovation. In IIE Annual Conference.", Proceedings, Institute of Industrial and Systems Engineers (IISE), January 2015, pp. 1496.

[3] F. Rioja and N. Valev, "Does one size fit all? A reexamination of the finance and growth relationship", vol. 74, Journal of Development Economics, 2004, pp.429-447.

[4] E. K. K. Lartey, "A note on the effect of financial development on economic growth", vol. 17, Applied Economics Letters, 2010, pp. 685687.

[5] Financial sector assessment, A handbook, the World Bank, 2005.

[6] P. Aghion, P. Howitt and David Mayer-Foulkes, " The effect of financial development on convergence: theory and evidence.", vol. 120, Quarterly Journal of Economics, 2005, pp. 173-222.

[7] R. Kelley and G. Mavrotas , " Savings and financial sector development: panel cointegration evidence from Africa", val. 14, European Journal of Finance, 2008, pp. 563-581.

[8] S. Çiftçioğlu and M. Almasifard, "The response of consumption to alternative measures of financial development and real interest rate in a sample of central and east European countries", val. 3, Journal of Economics and Development Studies, 2015, pp. 1-6

[9] M. Almasifard, "An econometric analysis of financial development's effects on the share of final consumption expenditure in gross domestic product", Eastern Mediterranean University, June 2013 